\title{
HUBUNGAN ANTARA NOMOPHOBIA DENGAN KEPERCAYAAN DIRI
}

\author{
Shanty Sudarji \\ Program Studi Psikologi Universitas Bunda Mulia \\ gbu120711@gmail.com
}

\begin{abstract}
Technology such as smartphones is growing rapidly. Development of applications such as instant messengers, social networks even easier for everyone to communicate, the distance is not an obstacle now. In addition to ease of access, the smartphone can also give confidence to users, in addition to models of smartphones increasingly stylish, applications that can be installed therein can make smartphone users are always updated with the latest news. The psychological impact caused by the use of smartphones on individuals and society in general about changing behavior and habits before and after use. Nomophobia (no-mobile-phone-phobia) is a type of phobia characterized by excessive fear if someone loses or does not exist near his smartphone. People who experience nomophobia always live in fear and are always anxious to put or keep his smartphone, so always take it anywhere to go. The questionnaire used to nomophobia is an adaptation of the questionnaire Yildirim (2014), composed of 4 dimensions with 20 statements. As for the questionnaire confidence, based on the theory of Justice (2002) derived into 3 dimensions with 46 statements. Results of the reliability values obtained for instruments confidence of 0.944, while the result of the reliability values for nomophobia instrument amounted to 0,939. The results of the data analysis of the correlation between nomophobia and confidence showed a $p$-value $=0.626>\alpha=0.05$. This shows that there is no relationship between nomophobia with confidence.
\end{abstract}

Keywords: Smartphone, Nomophobia, Confidence

\begin{abstract}
ABSTRAK
Teknologi seperti smartphone yang semakin berkembang dengan pesat menjadikan era informasi semakin mudah diakses. Muncul dan berkembangnya aplikasi seperti instant messenger, social network semakin memudahkan setiap orang untuk berkomunikasi, jarak kini bukanlah menjadi halangan. Selain untuk kemudahan akses, smartphone juga dapat memberikan rasa percaya diri bagi penggunanya, selain dengan model-model smartphone yang semakin stylish, aplikasi yang dapat diinstalasi didalamnya dapat membuat pengguna smartphone selalu update dengan berita-berita terkini. Dampak psikologis yang diakibatkan oleh penggunaan smartphone pada individu, kelompok dan masyarakat pada umumnya terkait dengan perubahan perilaku dan kebiasaan sebelum dan sesudah menggunakannya. Nomophobia (no-mobile-phone-phobia) adalah jenis fobia yang ditandai dengan ketakutan berlebih jika seseorang kehilangan atau tidak berada dekat dengan smartphone-nya. Orang yang mengalami nomophobia selalu hidup dalam kekhawatiran dan selalu cemas dalam meletakkan atau menyimpan smartphone miliknya, sehingga selalu membawanya kemanapun pergi. Kuesioner yang digunakan untuk nomophobia merupakan kuesioner adaptasi dari Yildirim (2014), terdiri dari 4 dimensi yang berisi 20 pernyataan. Sedangkan untuk kuesioner kepercayaan diri, berdasarkan teori dari Hakim (2002) yang diturunkan kedalam 3 dimensi yang berisi 46 pernyataan. Hasil nilai reliabilitas yang didapatkan untuk instrumen kepercayaan diri sebesar 0,944, sedangkan hasil nilai reliabilitas untuk instrumen nomophobia sebesar 0,939. Hasil analisa data korelasi antara nomophobia dan kepercayaan diri menunjukkan nilai $p=0,626>$ $\alpha=0,05$. Hal ini menunjukkan bahwa tidak terdapat hubungan antara nomophobia dengan kepercayaan diri.
\end{abstract}

Kata kunci:Smartphone, Nomophobia, kepercayaan diri

\section{PENDAHULUAN \\ 1.1 Latar Belakang}

Infrastuktur internet yang semakin berkembang dengan cepat menjadikan era informasi semakin terbuka; dengan smartphone, kini setiap orang memiliki akses ke seluruh dunia dengan internet, menjadikan informasi cepat tersebar. Muncul dan berkembangnya perangkat lunak seperti chat, instant messenger, social network semakin memudahkan setiap orang untuk berkomunikasi, jarak kini bukanlah 
menjadi halangan (Pradana, Muqtadiroh \& Nisafani, 2016). Fungsi komunikasi dalam kehidupan sehari-hari menyangkut banyak aspek, melalui komunikasi juga seseorang menyampaikan apa yang ada dalam benak pikiran dan perasaan kepada orang lain baik secara langsung maupun tidak (Mayangsari \& Ariana, 2015). Interaksi individu dengan smartphone sangat mempengaruhi perilaku interpersonal dan kebiasaan sosial. Teknologi komunikasi juga membuat perubahan dalam interaksi masyarakat dengan dunia, persepsi pada interaksi yang nyata dan interaksi lewat smartphone (Lucia, dalam Mayangsari \& Ariana, 2015). Dampak psikologis yang diakibatkan oleh penggunaan teknologi pada individu, kelompok dan masyarakat pada umumnya terkait dengan perubahan perilaku dan kebiasaan sebelum dan sesudah menggunakan smartphone (King \& Valenca, 2013).Darmawan (2012) mengemukakan bahwa perkembangan teknologi komunikasisangat berdampak pada kehidupan sosial masyarakat. Dampak positif yang dapat dirasakan dari perkembangan teknologi komunikasi antara lain kemudahan dalam berkomunikasi dengan kerabat yang jaraknya sangat jauh sekalipun. Dengan adanya teknologi jaringan membuat seseorang dapat mengakrabkan diri kembali dengan temanteman lama, dan juga sanak saudara lainnya. Dengan menggunakan smartphone yang di isi dengan aplikasi chat, email, telepon, dan media sosial kita dapat bertukar informasi dalam hitungan detik. Selain itu dampak positif lainnya adalah masyrakat akan lebih mudah menyebarkan kebaikan antar umat manusia, misalnya saja terdapat sebuah bencana alam pada suatu daerah tertentu maka orang yang sedang dekat dengan lokasi dapat mengabarkan atau menyebarkan informasi bahwa sedang terjadi musibah bencana alam di lokasi orang itu sedang berada. Dengan demikian apabila ada sebuah organisasi atau orang tertentu yang ingin mengadakan penggalangan dana untuk membantu beban korban-korban bencana alam melalui media ini seseorang atau organisasi tersebut akan dengan mudah menyebarkan informasinya yang nantinya akan mempermudah untuk melakukan pengumpulan donasi kepada orang yang membutuhkan tersebut. Seperti kita ketahui sekarang jaringan internet sudah begitu luas bahkan tidak hanya di daerah perkotaan saja tetapi juga di pedesaan.Meskipun perubahan teknologi komunikasi ini membawa dampak positif kepada masyarakat dalam hal kehidupan sosial, hal ini juga membawa dampak negatif. Dampak negatif dengan adanya perkembangan teknologi komunikasi dan informasi ini adalah menurunnya kepedulian masyarakat terhadap orang-orang yang ada disekitarnya. Sering dijumpai sekumpulan keluarga besar, lengkap dari orangtua dan anak-anaknya berserta asisten rumah tangga duduk dalam satu meja makan bersama-sama tetapi tidak saling berbincang, mereka seakan-akan sibuk dengan smartphone-nya masing-masing untuk bercengkrama dengan orang lain yang jaraknya lebih jauh dibanding keluarganya yang sedang berada di dekatnya.

Penggunaan smartphonejuga merupakan suatu hal yang wajar di masa kini. Smartphone sudah seperti menjadi benda yang wajib dibawa kemanapun individu berada, fungsinya bisa menjadi perangkat bermain game, berjejaring sosial, mengedit foto dan video, dan lainnya. Otomatis, hadirnya beragam fitur menarik ini semakin "mengikat" pengguna agar terus bermain dengan smartphone-nya sehingga menjadi kecanduan (Reza, 2015). Penggunaan smartphone juga secara tidak langsung dapat menjadi ukuran eksistensi seseorang dalam kelompoknya. Sebuah organisasi riset di Inggris yang meneliti kecemasan yang diderita oleh pengguna smartphone menemukan bahwa hampir 53\% pengguna smartphone di Inggris cenderung menjadi cemas ketika kehilangan smartphone mereka, kehabisan baterai, atau tidak memiliki jangkauan jaringan (Bivin, 2013). No-mobile-phone-phobia atau yang biasa disebut nomophobia baru-baru ini telah digunakan untuk menggambarkan ketidaknyamanan atau kecemasan yang disebabkan oleh tidak berada dekat dengan perangkat komunikasi virtual seperti telepon selular (King \& Valenca, 2013). Berdasarkan survei yang dilakukan Secur 
Evoy, sebuah perusahaan yang mengkhususkan diri dalam password digital, yang melakukan survei terhadap 1.000 orang di Inggris menyimpulkan bahwa mahasiswa masa kini mengalami nomophobia, yaitu perasaan cemas dan takut jika tidak bersama telepon selularnya. Hasil survei menunjukan, $66 \%$ responden mengaku tidak bisa hidup tanpa telepon selulernya. Persentase ini semakin meningkat pada responden berusia 18 dan 24 tahun. Sebanyak $77 \%$ responden di antara kelompok usia ini mengalami nomophobia (Ngafifi \& Wonosobo, 2015).

Banyak individu yang merasakan kepercayaan dirinya meningkat jika dapat selalu tampak memegang smartphone yang dimilikinya, hal ini semakin didukung oleh perkembangan social media yang begitu pesat, smartphone juga telah menjadi gaya hidup untuk dapat pengakuan dalam kelompok dan untuk meningkatkan kepercayaan diri seseorang. Namun, sangat disayangkan kebanyakan individu kini telah kecanduan smartphone, seolah-olah mereka menemukan dunia sendiri dan sulit untuk melepaskan diri dari benda tersebut. Benua Asia memiliki jumlah pecandu smartphone terbanyak dan diprediksi akan terus meningkat. Survei terkini yang dilakukan Science Direct mengungkap, 25\% dari pengguna smartphone yang mayoritas remaja di Asia mengidap nomophobia. Lebih lanjut, survei tersebut menjelaskan 72 persen di antara anak-anak berusia 11-12 tahun di Korea Selatan menghabiskan waktunya 5,4 jam sehari untuk menggunakan smartphone. Jumlah ini belum digabungkan dengan total penggunaan smartphone oleh remaja di berbagai negara lain di Asia, termasuk Singapura, yang rupanya memiliki tingkat penggunaan smartphone tertinggi di dunia. Padahal, populasinya hanya sebanyak 6 juta jiwa saja. Hal tersebut, dipandang Chong Ee-Jau, peneliti dari Touch Cyber Wellness Centre di Singapura, sebagai fenomena yang "mengerikan". Jika tidak ditanggulangi, maka penggunaan smartphone akan disalahgunakan dan menjadi negatif (Reza, 2015).

\subsection{Tujuan Penelitian}

Penelitian ini bertujuan untuk mengetahui hubungan nomophobia dengan kepercayaan diri.

\section{TINJAUAN PUSTAKA \\ 2.1 Kepercayaan Diri}

Percaya diri berasal dari bahasa Inggris yakni self confidence yang artinya percaya pada kemampuan, kekuatan dan penilaian diri sendiri. Jadi dapat dikatakan bahwa penilaian tentang diri sendiri adalah berupa penilaian yang positif. Penilaian positif inilah yang nantinya akan menimbulkan sebuah motivasi dalam diri individu untuk lebih mau menghargai dirinya. Pengertian secara sederhana dapat dikatakan sebagai suatu keyakinan seseorang terhadap gejala aspek kelebihan yang dimiliki oleh individu dan keyakinan tersebut membuatnya merasa mampu untuk bisa mencapai berbagai tujuan hidupnya (Thursan, 2002).

Menurut Perry, kepercayaan diri yaitu suatu kemampuan untuk dapat mempercayai kemampuan diri sendiri dan merasa positif terhadap hal yang bisa dilakukan dan tidak mengkhawatirkan tentang hal yang tidak bisa dilakukan (dalam Rombe, 2014). Brennecke dan Amich (dalam Karyo, 2013), mengemukakan bahwa kepercayaan diri merupakan suatu perasaan atau sikap yang tidak perlu untuk membandingkan dengan orang lain dikarenakan sudah merasa cukup aman dan tahu mengenai apa yang dibutuhkan didalam hidup ini. Selain itu, kepercayaan diri juga diartikan sebagai salah satu aspek kepribadian atau konsep diri yang penting dalam hidup seseorang karena dengan kepercayaan diri, seseorang mampu mengaktualisasikan segala potensi di dalam dirinya (Lauster dalam Longkutoy, 2015). Hal ini diperkuat oleh Davies (dalam Idrus dan Rohmiati, 2011), dimana rasa percaya diri merupakan keyakinan terhadap kemampuan yang dimiliki, keyakinan pada suatu maksud ataupun tujuan di dalam kehidupan, serta percaya bahwa akal budi mampu untuk melaksanakan apa yangdiinginkan, direncanakan, dan juga diharapkan. 
Selain itu, Hakim mendefinisikan kepercayaan diri juga dapat diartikan sebagai suatu keyakinan terhadap segala aspek kelebihan yang dimiliki, dan keyakinan tersebut membuatnya merasa mampu mencapai berbagai tujuan hidupnya (dalam Wahyuni, 2014).Faktor-faktor yang mempengaruhi rasa percaya diri pada seseorang menurut Hakim (dalam Sembiring, 2014) antara lain adalah keadaan keluarga yang merupakan lingkungan hidup pertama dan utama dalam kehidupan setiap manusia, lingkungan sangat mempengaruhi pembentukan awal rasa percaya diri pada seseorang. Rasa percaya diri merupakan suatu keyakinan seseorang terhadap segala aspek kelebihan yang ada pada dirinya dan diwujudkan dalam tingkah laku sehari-hari. Berdasarkan pengertian di atas, rasa percaya diri baru bisa tumbuh dan berkembang baik sejak kecil,jika seseorang berada di dalam lingkungan keluarga yang baik, namun sebaliknya jika lingkungan tidak memadai menjadikan individu tersebut untuk percaya diri maka individu tersebut akan kehilangan proses pembelajaran untuk percaya pada dirinya sendiri. Pendidikan keluarga merupakan pendidikan pertama dan utama yang sangat menentukan baik buruknya kepribadian seseorang.

\subsection{Nomophobia}

Nomophobia (no-mobile-phonephobia) adalah jenis fobia yang ditandai ketakutan berlebih jika seseorang kehilangan ponselnya. Orang yang menderita nomophobia selalu hidup dalam kekhawatiran dan selalu cemas dalam meletakkan atau menyimpan smartphone miliknya, sehingga selalu membawanya kemanapun pergi. Penderita nomophobia bahkan dapat memeriksa smartphonenya hingga 34 kali sehari dan sering membawanya hingga ke toilet. Ketakutan tersebut termasuk dalam hal kehabisan baterai, melewatkan telepon atau sms, dan melewatkan informasi penting dari jejaring sosial (Mayasari, 2012). Adapun ciri-ciri orang mengidap nomophobia sebagai berikut (dalam Pradana, Muqtadiroh \& Nisafani, 2016):a). Menghabiskan waktu menggunakan telepon seluler, mempunyai satu atau lebih gadget dan selalu membawa charger, $b$ ). Merasa cemas dan gugup ketika telepon seluler tidak tersedia dekat atau tidak pada tempatnya. Selain itu juga merasa tidak nyaman ketika gangguan atau tidak ada jaringan serta saat baterai lemah, c). Selalu melihat dan mengecek layar telepon seluler untuk mencari tahu pesan atau panggilan masuk. Hal ini seringkali disebut ringxiety yaitu perasaan seseorang yang menganggap telepon selularnya bergetar atau berbunyi. d). Tidak mematikan telepon selular dan selalu sedia 24 jam, e). Kurang nyaman berkomunikasi secara tatap muka, f). Mengeluarkan biaya yang besar untuk telepon selular.

Adapun aspek atau dimensi dari nomophobia adalah a). tidak bisa berkomunikasi (not being able to communicate), b). kehilangan konektivitas (Losing Connectedness), c). tidak mampu mengakses informasi (not being able to access information), d). menyerah pada kenyamanan (giving up convenience). Aspek pertama merujuk kepada adanya perasaan kehilangan ketika secara tiba-tiba terputus komunikasi dengan orang lain dan atau tidak dapat menggunakan pelayanan disaat tibatiba membutuhkan komunikasi. Aspek kedua merujuk pada perasaan kehilangan ketika tidak dapat terhubung dengan layanan pada smartphone dan tidak dapat terhubung pada identitas sosialnya terkhusus di media sosial. Aspek ketiga menggambarkan perasaan ketidaknyamanan ketika tidak dapat mengambil atau mencari informasi melalui smartphone. Sedangkan aspek keempat mencerminkan keinginan untuk memanfaatkan kenyamanan memiliki smartphone (Yildirim, 2014).

\section{METODE PENELITIAN}

Prosedur penelitian terdiri dari dua tahap, yaitu tahap persiapan dan tahap pelaksanaan penelitian. Pada tahap persiapan, peneliti mencari fenomena mengenai kaitan antara nomophobia dan kepercayaan diri. Setelah itu, akan menyusun alat ukur kepercayan diri dan nomophobia serta melakukan tryout untuk proses analisa item, reliabilitas dan validitas. Kemudian menghitung korelasi antara kedua 
variabel.Teknik pengambilan sampel yang digunakan yaitu non-probability sampling (non-random) yang dimana populasinya tidak diketahui secara keseluruhan, probabilitas individu tidak dapat diketahui, dan pemilihan didasarkan pada faktor-faktor seperti akal sehat atau upaya untuk mempertahankan perwakilan dan menghindari bias (Gravetter dan Forzano,2009) melalui metode accidental sampling.

Instrumen yang digunakan adalah kuesioner. Kuesioner merupakan teknik pengumpulan data yang dilakukan melalui pemberian seperangkat pertanyaan ataupun pernyataan yang tertulis kepada responden untuk dijawabnya (Sugiyono, 2014). Kuesioner yang digunakan untuk nomophobia merupakan kuesioner adaptasi dari Yildirim (2014), terdiri dari 4 dimensi dengan 20 pernyataan. Kuesioner ini diisi dengan menggunakan skala Likert melalui 7 alternatif jawaban dari sangat tidak setuju hingga sangat setuju. Tidak ada pembedaan aitem pada kuesioner ini, yang ditunjukkan dengan penyesuaian skala 1-7 pada setiap aitem yang dipakai untuk mendukung hasil akhir skor tinggi atau rendah.

Sedangkan untuk kuesioner kepercayaan diri, berdasarkan teori dari Hakim (2002) yang diturunkan kedalam 3 dimensi dengan 46 pernyataan. Kuesioner ini juga diisi dengan menggunakan skala Likert melalui 4 alternatif jawaban dari sangat tidak setuju hingga sangat setuju. Butir pernyataan juga mengandung pernyataan yang bersifat mendukung (favorable) atau tidak mendukung (unfavorable).

Dalam penelitian ini, dilakukan uji coba kepada 30 subjek di lingkungan kampus "BM". Dari hasil uji coba pada kuesioner nomophobia, didapatkan reliabilitas sebesar 0,939 dengan rentang validitas 0,256-0,877. Sedangkan untuk kuesioner kepercayaan diri, didapatkan hasil reliabilitas sebesar 0,944 dengan rentang validitas sebesar 0,385-0,739. Pada kuesioner kepercayaan diri didapatkan 7 aitem gugur dari 46 aitem. Aitem dibuang dikarenakan jika $\mathrm{N}=30$, maka product moment sebesar 0,361. Oleh karena itu, aitem dinyatakan valid apabila nilai corrected item total correlation lebih besar dari 0,361 .

Tabel 1.Blueprint Nomophobia Sebelum dan Setelah Uji Coba

\begin{tabular}{lcc}
\hline \multicolumn{1}{c}{ Dimensi } & \multicolumn{1}{c}{ Item } & Total \\
\hline $\begin{array}{l}\text { Not being } \\
\text { able to } \\
\text { communicate }\end{array}$ & $10,11,12,13,14,15$ & 6 \\
$\begin{array}{l}\text { Losing } \\
\text { connectedness }\end{array}$ & $16,17,18,19,20$ & 5 \\
$\begin{array}{l}\text { Not being } \\
\text { able to access } \\
\text { information }\end{array}$ & $1,2,3,4$ & 4 \\
$\begin{array}{l}\text { Giving up } \\
\text { convenience }\end{array}$ & $5,6,7,8,9$ & \\
& & 5 \\
\hline
\end{tabular}

Tabel 2.Blueprint Kepercayaan Diri setelah Uji Coba

\begin{tabular}{|c|c|c|c|c|}
\hline \multirow{2}{*}{$\begin{array}{l}\text { Dimen- } \\
\text { si }\end{array}$} & \multirow{2}{*}{ Indikator } & \multicolumn{2}{|c|}{ Item } & \multirow{2}{*}{ Jml } \\
\hline & & Fav & Unfav & \\
\hline \multirow[t]{2}{*}{$\begin{array}{l}\text { Keyakin } \\
\text { an Diri }\end{array}$} & $\begin{array}{l}\text { Kemauan } \\
\text { dan Usaha }\end{array}$ & $1,7,20$ & $\begin{array}{l}27,32, \\
39\end{array}$ & 6 \\
\hline & Optimis & $\begin{array}{l}2,8,14, \\
45\end{array}$ & 21,40 & 6 \\
\hline \multirow{3}{*}{$\begin{array}{l}\text { Sikap } \\
\text { Positif }\end{array}$} & Mandiri & 9 & 22 & 2 \\
\hline & $\begin{array}{l}\text { Tidak } \\
\text { Mudah } \\
\text { Menyerah }\end{array}$ & $\begin{array}{l}10,23 \\
28,35\end{array}$ & $\begin{array}{l}3,16,4 \\
6\end{array}$ & 7 \\
\hline & $\begin{array}{l}\text { Mampu } \\
\text { Menyesuai } \\
\text { kan diri }\end{array}$ & $\begin{array}{l}4,11,3 \\
6,42\end{array}$ & $\begin{array}{l}17,24, \\
29\end{array}$ & 7 \\
\hline \multirow{3}{*}{$\begin{array}{l}\text { Memanf } \\
\text { aatkan } \\
\text { Kelebih } \\
\text { an }\end{array}$} & & $5,12,1$ & 25,30 & 6 \\
\hline & $\begin{array}{l}\text { Memiliki } \\
\text { dan } \\
\text { memanfaat } \\
\text { kan } \\
\text { kelebihan }\end{array}$ & 8,37 & & \\
\hline & $\begin{array}{l}\text { Memiliki } \\
\text { Mental dan } \\
\text { Fisik yang } \\
\text { Menunjang }\end{array}$ & $\begin{array}{l}6,13,1 \\
9\end{array}$ & 38,43 & 5 \\
\hline Total & & & & 39 \\
\hline
\end{tabular}


Penelitian ini juga menggunakan uji normalitas yang bertujuan untuk mengetahui hasil penelitian berdistribusi normal atau tidak. Data dapat dikatakan normal apabila $\mathrm{p}>0,5$ dan dikatakan tidak normal apabila $\mathrm{p}<0,5$. Uji normalitas dalam penelitian ini menggunakan perhitungan One-Sampe Kolmogorof-Smirnov Test. Analisis hubungan (korelasi) merupakan sebuah bentuk analisis data dalam penelitian yang bertujuan untuk mengetahui kekuatan atau bentuk arah hubungan antara dua variabel ataupun lebih dan juga besarnya pengaruh yang diakibatkan oleh variabel bebas terhadap variabel terikat (Siregar, 2013).

\section{HASIL DAN PEMBAHASAN}

Penelitian ini melibatkan 48 responden laki-laki dengan persentase sebesar 29,6 \% dan 114 responden perempuan dengan persentase 70,4\%. Sehingga, total responden yang terlibat dalam penelitian ini berjumlah 162 orang.

Tabel 3.Persentase Responden Berdasarkan Jenis Kelamin

\begin{tabular}{|c|c|c|c|}
\hline & Freq Percent & $\begin{array}{l}\text { Valid } \\
\text { Percent }\end{array}$ & $\begin{array}{l}\text { Cumulative } \\
\text { Percent }\end{array}$ \\
\hline Pria & 29.6 & 29.6 & 29.6 \\
\hline Valid Wanita & $114 \quad 70.4$ & 70.4 & 100.0 \\
\hline Total & 162100.0 & 100.0 & \\
\hline
\end{tabular}

Usia responden tidak dibatasi karena peneliti ingin melihat dan mendapatkan hasil yang lebih bervariasi, sehingga diperoleh rentang usia responden yang tergolong kedalam 9 kategori dari usia 11-55 tahun. Terdapat 2 orang responden di rentang usia 11-15 tahun dengan persentase sebesar 1,2 $\%, 112$ orang responden berusia $16-20$ tahun dengan persentase sebesar $69,1 \%, 26$ orang responden berusia 21-25 tahun dengan persentase sebesar $16 \%, 2$ orang responden berusia 26-30 tahun dengan persentase 1,2 $\%, 6$ orang responden berusia 31-35 tahun dengan persentase sebesar $3,7 \%, 5$ orang responden berusia 36-40 tahun dengan persentase sebesar 3,1\%, 3 orang responden berusia 41-45 tahun dengan persentase sebesar $1,9 \%, 3$ orang responden berusia 46-50 dengan persentase sebesar $1,9 \%$, dan
3 orang responden berusia 51-55 tahun dengan persentase sebesar $1,9 \%$.

Tabel 4.Persentase Usia Responden Penelitian

\begin{tabular}{|c|c|c|c|c|c|}
\hline & & Freq & Percent & $\begin{array}{c}\text { Valid } \\
\text { Percent }\end{array}$ & $\begin{array}{c}\text { Cumulative } \\
\text { Percent }\end{array}$ \\
\hline & $11-15$ & 2 & 1.2 & 1.2 & 1.2 \\
\hline & $16-20$ & 112 & 69.1 & 69.1 & 70.4 \\
\hline & $21-25$ & 26 & 16.0 & 16.0 & 86.4 \\
\hline & $26-30$ & 2 & 1.2 & 1.2 & 87.7 \\
\hline Volid & $31-35$ & 6 & 3.7 & 3.7 & 91.4 \\
\hline valla & $36-40$ & 5 & 3.1 & 3.1 & 94.4 \\
\hline & $41-45$ & 3 & 1.9 & 1.9 & 96.3 \\
\hline & $46-50$ & 3 & 1.9 & 1.9 & 98.1 \\
\hline & $51-55$ & 3 & 1.9 & 1.9 & 100.0 \\
\hline & Total & 162 & 100.0 & 100.0 & \\
\hline
\end{tabular}

Dari 162 responden yang terlibat di dalam penelitian ini, diketahui 125 orang merupakan mahasiswa dengan persentase sebesar $77,2 \%, 11$ orang merupakan pelajar dengan persentase sebesar $6,8 \%$, dan 26 orang merupakan karyawandengan persentase sebesar $16 \%$.

Tabel 5. Persentase Pekerjaan Responden Penelitian

\begin{tabular}{|c|c|c|c|c|c|}
\hline \multicolumn{6}{|c|}{ Penelitian } \\
\hline & & Freq & Percent & $\begin{array}{c}\text { Valid } \\
\text { Percent }\end{array}$ & $\begin{array}{l}\text { Cumulati } \\
\text { ve Percent }\end{array}$ \\
\hline \multirow{4}{*}{ Valid } & Mahasiswa & 125 & 77.2 & 77.2 & 77.2 \\
\hline & Pelajar & 11 & 6.8 & 6.8 & 84.0 \\
\hline & Karyawan & 26 & 16.0 & 16.0 & 100.0 \\
\hline & Total & 162 & 100.0 & 100.0 & \\
\hline
\end{tabular}

Domisili tinggal responden terbagi kedalam 13 wilayah. Sebanyak 92 orang responden berdomisili di Jakarta Utara dengan persentase $56,8 \%, 18$ orang responden berdomisili di Jakarta Barat dengan persentase sebesar $11,1 \%, 4$ orang responden berdomisili di Jakarta Timur dengan persentase sebesar $2,5 \%, 3$ orang responden berdomisili di Jakarta Selatan dengan persentase sebesar $1,9 \%, 8$ orang berdomisili di Jakarta Pusat dengan persentase sebesar 4,9 \%, 16 orang responden berdomisili di Bekasi dengan persentase sebesar 9,9\%, 3 orang responden berdomisili di Depok dengan persentase sebesar $1,9 \%, 3$ orang responden berdomisili di Cengkareng dengan ersentase 
sebesar $1,9 \%, 9$ orang berdomisili di Tangerang dengan persentase sebesar 5,6 \%, 3 orang responden berdomisili di Bogor dengan persentase sebesar 5,6 \%, dan terdapat masing-masing 1 orang responden yang berdomisili di Bintaro, Serpong dan Bandung dengan persentase sebesar 0,6 persen pada ketiga wilayah tersebut.

Berdasarkan hasil perhitungan reliabilitas dan validitas yang dilakukan melalui program komputerisasi SPSS 21, nilai reliabilitas instrumen nomophobia adalah sebesar 0,939 yang dapat diartikan bahwa instrument ini reliabel. Sedangkan validitas dari instrumen nomophobia berada pada rentang 0,256-0,877. Nilai reliabilitas dari instrumen kepercayaan diri adalah sebesar 0,944 yang dapat diartikan yaitu instrumen tersebut reliabel. Sedangkan validitas dari instrument kepercayaan diri berada pada rentang 0,385-0,739.

Berdasarkan tabel One-Sample

Kolmogorov-Smirnov Test dapat diketahui bahwa nilai hasil uji normalitas dari 162 responden dengan instrumen nomophobia sebesar 0,954 dan kepercayaan diri sebesar 0,784 . Data dapat dikatakan normal apabila $\mathrm{p}>0,5$ dan dikatakan tidak normal apabila $\mathrm{p}<0,5$. Dari hasil perhitungan yang didapat, dapat disimpulkan bahwa data pada penelitian ini merupakan data yang berdistribusi normal.

Dalam menguji ada atau tidaknya hubungan antara nomophobia dengan kepercayaan diri, maka dilakukan uji korelasi pearson. Hal ini dikarenakan data penelitian ini berdistribusi normal.

Tabel 6. Uji Korelasi

Nomophobia dan Kepercayaan Diri

\begin{tabular}{lcc}
\hline & $\begin{array}{c}\text { Nomo- } \\
\text { phobia }\end{array}$ & $\begin{array}{c}\text { Keper- } \\
\text { cayaan Diri }\end{array}$ \\
\hline $\begin{array}{l}\text { Nomo- Pearson Correlation } \\
\text { phobia Sig. (2-tailed) }\end{array}$ & 1 & .039 \\
N & 162 & .626 \\
Keper- Pearson correlation & .039 & 162 \\
$\begin{array}{l}\text { cayaandiSig. (2-tailed) } \\
\text { ri N }\end{array}$ & .626 & \\
\hline
\end{tabular}

Hasil analisa yang didapatkan dari data korelasi antara nomophobia dengan kepercayaan diri menunjukkan koefisien korelasi yang positif $(r=0,039)$ yang menandakan jika variabel $X$ atau nomophobia naik, maka variabel $\mathrm{Y}$ yaitu kepercayaan diri juga naik. Sedangkan jika variabel $\mathrm{X}$ turun maka variabel $\mathrm{Y}$ juga akan turun. Dengan nilai $\mathrm{p}=0,626>\alpha=0,05$, maka H0 diterima atau dengan kata lain tidak terdapat hubungan antara nomophobia dengan kepercayaan diri.

Hal tersebut dapat dikarenakan adanya faktor-faktor lain yang dapat berperan dalam menentukan tinggi rendahnya atau ada tidaknya kepercayaan diri seseorang. Faktor-faktor yang mempengaruhi kepercayaan diri seseorang menurut Hapasari dan Primastuti (2014) terdiri dari dua faktor yaitu faktor internal dan faktor eksternal. Faktor internal meliputi kondisi fisik, usia, jenis kelamin, dan harga diri. Sedangkan faktor eksternal meliputi tingkat pendidikan, dukungan sosial dan kesuksesan dalam mencapai tujuan.

Kondisi fisik merupakan faktor yang mempengaruhi kepercayaan diri secara internal, dimana faktor fisik yang menunjang atau dengan kata lain individu dengan fisik yang kurang sempurna dapat merasakan ada sesuatu yang kurang di dalam dirinya (Suryabrata dalam Hapasari dan Primastuti, 2014). Di masa remaja terutama, kepercayaan diri remaja menjadi rapuh yang dikarenakan adanya faktor kegagalan di masa ini merupakan suatu hal yang menyakitkan sehingga tidak sedikit remaja yang mengalami rasa tidak percaya diri baik pada anak laki-laki ataupun perempuan (Al-Mighwar dalam Hapasari dan Primastuti, 2014). Memiliki smartphone bagi remaja mungkin dapat membuat mereka merasa diterima oleh teman sebayanya, namun benda tersebut menjadi tidak terlalu penting jika dibandingkan dengan kondisi fisik dan penampilan yang sempurna yang mereka miliki.

Faktor berikutnya yang dapat mempengaruhi kepercayaan diri yaitu jenis kelamin dimana perubahan yang terjadi di usia remaja baik perubahan fisik ataupun psikologis biasanya lebih banyak memiliki pengaruh pada anak perempuan dikarenakan pertumbuhan pada remaja putri jauh lebih 
cepat walaupun demikian, remaja putra mempunyai kesempatan lebih banyak untuk dapat menyesuaikan diri dibandingkan dengan remaja putri (Hurlock dalam Hapasari dan Primastuti, 2014).

Faktor internal terakhir yang juga dapat mempengaruhi kepercayaan diri yaitu harga diri yang merupakan landasan untuk rasa percaya diri dimana dengan adanya perasaan bahagia akibat penghargaan yang diterima merupakan hal yang penting dalam menumbuhkan rasa percaya diri (Murdoko, 2004; Mappiare, 1982 dalam Hapasari dan Primastuti, 2014). Banyak hal selain memiliki smartphone yang dapat membuat seseorang menjadi percaya diri, misalnya apresiasi yang diberikan oleh lingkungan sekitar yang dapat berupa pujian ataupun hal lainnya.

Berikutnya adalah faktor eksternal yang meliputi tingkat pendidikan, dukungan sosial dan kesuksesan dalam mencapai tujuan.Faktor eksternal yang pertama yaitu tingkat pendidikan dimana memiliki pengaruh dalam menentukan kepercayaan diri. Orang yang memiliki tingkat pendidikan lebih tinggi memiliki banyak pengalaman di dalam hidupnya terutama ia lebih mengenal terkait kelebihan dan kelemahan dirinya yang disesuaikan dengan standar keberhasilannya sehingga individu tersebut memiliki kepercayaan diri di dalam menangani sesuatu tanpa mempunyai perasaan takut (Monks dalam Hapsari dan Primastuti, 2014).

Faktor eksternal kedua ialah adanya dukungan sosial pada individu yang didapatkan dari lingkungan sekitar yang berguna untuk menentukan terwujudnya kepercayaan diri (Sari dalam Hapsari dan Primastuti, 2014). Terakhir, faktor kesuksesan dimana semakin banyak kesuksesan yang diperolehnya, semakin juga orang tersebut juga memiliki kepercayaan diri di dalam hidupnya.

\section{SIMPULAN DAN SARAN}

Hasil analisa data korelasi antara nomophobia dan kepercayaan diri menunjukkan nilai $\mathrm{p}=0,626>\alpha=0,05$. Hal ini menunjukkan bahwa tidak terdapat hubungan antara nomophobia dengan kepercayaan diri. Terdapat faktor-faktor lain yang lebih kuat yang dapat mempengaruhi kepercayaan diri seseorang.

Kajian mengenai nomophobia masih terbatas, terutama di Indonesia. Topik ini menarik untuk diteliti karena erat kaitannya dengan bidang ilmu psikologi. Selanjutnya dapat dilakukan penelitian dengan skala yang lebih luas. Data kontrol yang dapat berpengaruh kepada hasil penelitian seperti domisili, usia, pendidikan, dan pekerjaan dapat diperluas cakupannya sehingga hasil penelitian lebih dapat digeneralisasi dan dapat memberikan sumbangan penelitian yang bermanfaat bagi bidang ilmu psikologi.

Nomophobia dapat diteliti lebih dalam dan dihubungkan dengan variabelvariabel lainnya seperti agresivitas, konsep diri, ataupun konsep-konsep psikologi lainnya yang memiliki hubungan sebab akibat dengan nomophobia. Penggunaan instrumen penelitian juga perlu ditingkatkan kualitasnya, misalnya dengan menggunakan lebih dari satu expert judgment untuk mengevaluasi lebih lanjut mengenai isi dari pernyataan yang digunakan, dan ketepatan penggunaan tata bahasa yang telah disusun.

\section{DAFTAR PUSTAKA}

Azwar,S. (2012). Reliabilitas dan Validitas. Yogyakarta: Pustaka Pelajar.

Creswell, J.W. (2014). Research Design Pendekatan Kualitatif, Kuantitatif, dan Mixed. Yogyakarta: Pustaka Pelajar.

Crocker. L. \& Algina, J.T. (2006). Introduction to Classical and Modern Test Theory. University of Florida.

Darmawan, D. (2012).Pendidikan Teknologi Informasi dan Komunikasi. Jakarta: PT Remaja Rosdakarya.

Febrianto, B., Herani, I., Supriyono, Y. (2013). "Hubungan Kepercayaan Diri dengan Kemampuan Hubungan Interpersonal pada Anggota UB (Universitas Brawijaya) Fitness Center”, 10, diunduh pada tanggal 21 
desember $2016 \quad$ dari

http://psikologi.ub.ac.id/wp-

content/uploads/2013/10/JURNAL4.p df

Graveter. F. J \& Forzano. L. B. (2009). Research Method Behavioral Sciences. United States : Wadsworth Cengage Learning.

Hapasari, A., Primastuti, E. (2014). Kepercayaan diri mahasiswi Papua ditinjau dari dukungan teman sebaya. Psikodemensia, 13 (1), diunduh pada tanggal 7 Februari 2017 dari journal.unika.ac.id/index.php/psi/artic le/download/278/269.

Idrus, M., Rohmiati, A. (2011). "Hubungan kepercayaan diri remaja dengan pola asuh orang tua etnis Jawa", diunduh pada tanggal 21 Desember 2016 dari https://www.google.com/url?sa=t\&rct $=\mathrm{j} \& \mathrm{q}=\&$ esrc $=\mathrm{s} \&$ source $=$ web $\& \mathrm{~cd}=2 \&$ ved=0ahUKEwiu0P3zgojRAhUEo48 KHSrSDtcQFgghMAE\&url=http\%3A $\% 2 \mathrm{~F} \% 2 \mathrm{Fkajian}$.uii.ac.id\%2Fwpcontent $\% 2$ Fuploads $\% 2$ F2011\%2F06 $\%$ 2FHUBUNGAN-

KEPERCAYAAN-DIRI-REMAJADENGAN_DR-M-IDRUSDKK.pdf\&usg=AFQjCNEB6x09dqG TQjCXJxzUy0eHy8mPYg\&bvm=bv. 142059868 ,d.c2I\&cad=rja

Kalaskar, P.B. (2015). "A study of awareness of development of nomophobia condition in smartphone user management students in Pune city”, Journal Incon, diunduh pada tanggal 21 Desember 2016 dari http://www.asmgroup.edu.in/incon/E $\% 20-$

$\% 20 J$ JUURNAL $\% 20 I N C O N \% 202015$ $/ \mathrm{INCON}-$

GM\%20Vol1/INCN15_GM_23.pdf

Kaparang, O. (2013). “Analisa gaya hidup remaja dalam mengimitasi budaya pop Korea melalui televisi”, Jurnal Acta Diurna, 2,2, diunduh pada tanggal 21 Desember 2016 dari http://ejournal.unsrat.ac.id/index.php/ actadiurna/article/viewFile/1138/916

Karyo. (2013). "Hubungan pola asuh orang tua dengan kepercayaan diri pada remaja (usia 15-17) tahun siswa kelas XI di SMA PGRI 3 Tuban tahun 2013", Jurnal Stikes, diunduh pada tanggal 21 Desember 2016 dari https://www.google.com/search?q=Hu bungan+Body+Image+dan+Kepercay aan+Diri+dengan+Perilaku+Konsumti $\mathrm{f}+\mathrm{Pada}+$ Remaja+Putri+di+SMA+Neg eri $+5+$ Samarinda+Sufrihana+Rombe $\&$ ie $=$ utf $-8 \&$ oe $=$ utf 8\#q=Hubungan+Pola+Asuh+Orang+ Tua+Dengan+Kepercayaan+Diri+Pad a+Remaja+\%28Usia+15-

17\%29+Tahun+Siswa+Kelas+Xi+Di+ SMA+PGRI+3+Tuban+Tahun+2013

Lahey. (2012). Psychology an introduction. New York : McGraw-Hill.

King, et al. (2014). "Nomophobia: impact of cell phone use interfering with symptoms and emotions of individuals with panic disorder compared with a control group", Clinical Practice \& Epidemiology in Mental Health, 10, diunduh pada tanggal 21 Desember 2016 dari https://benthamopen.com/contents/pdf /CPEMH/CPEMH-10-28.pdf

Lesmana, J.M. (2013). Dasar-dasar konseling. Jakarta : UI-Press.

Longkutoy, N., Sinolungan, J., Opod, H. (2015). "Hubungan pola asuh orang tua dengan kepercayaan diri siswa SMP kristen Ranotongkor Kabupaten Minahasa", 1,3, Jurnal e-biomedik, diunduh pada tanggal 21 Desember 2016, dari http://ejournal.unsrat.ac.id/index.php/ ebiomedik/article/view/6612/6133

MB, P., Madhukumar, S., Murthy, M. (2015). "A study on nomophobiamobile phone dependence, among students of a medical college in 
Bangalore", National Journal of community medicine, 2, 6, diunduh pada tanggal 21 Desember 2016 dari www.njcmindia.org/home/download/ 697

Mayasari, L. (2012). Tidak Bisa Jauh dari Ponsel? Anda Mungkin Menderita Nomophobia. Diunduh pada 7 Oktober 2016 dari Detik Health: http://health.detik.com/read/2012/09/2 1/175751/2030251/763/tidak-bisajauh-dari ponsel-anda-mungkinmenderita-nomophobia.

Mayangsari, A. P., Ariana, A. D. (2015). Hubungan antara self-esteem dengan kecenderungan nomophobia pada remaja. Jurnal psikologi klinis dan kesehatan mental. Vol. 04 No 3, Desember 2015. Surabaya: Fakultas Psikologi Universitas Airlangga.

Myers. A \& Hansen.C. (2012).Experimental Psychology. United States: Wadsworth Cengage Learning.

Ngafifi, M. (2015). Kemajuan teknologi dan pola hidup manusia dalam perspektif sosial budaya. Jurnal pembangunan pendidikan: fondasi dan aplikasi. Wonosobo: SMP Negeri 2 Sukoharjo.

Nazir, M. (2014) Metode Penelitian. Bogor : Ghalia Indonesia.

Papalia, D.E., Feldman, R.D. (2012). Experience Human Development. New York: McGraw-Hill.

Pradana, P.W., Muqtadiroh, F.A., Nisafani, A.S. (2016). "Perancangan aplikasi liva untuk mengurangi nomophobia dengan pendekatan gamifikasi”, Jurnal Teknik ITS, 1,5, diunduh pada tanggal 21 Desember 2016, dari http://ejurnal.its.ac.id/index.php/tekni k/article/view/14420

Reza. (2015). Makin Banyak Remaja di Asia yang Kecanduan Smartphone.
Diunduh dari Liputan 6.com pada Jumat, 7 Oktober 2016.

Rombe, S. (2014). "Hubungan body image dan kepercayaan diri dengan perilaku konsumtif pada remaja putri di SMA negeri 5 Samarinda", E-Journal Psikologi, 2,1, diunduh pada tanggal 21 Desember 2016 dari https://www.google.com/url?sa=t\&rct $=\mathrm{j} \& \mathrm{q}=\&$ esrc $=\mathrm{s} \&$ source $=$ web $\& \mathrm{~cd}=1 \&$ ved=0ahUKEwiVvO_sw4fRAhVKtY 8KHZHDBN4QFggbMAA\&url=http $\% 3 \mathrm{~A} \% 2 \mathrm{~F} \% 2 \mathrm{Fejournal} . p s i k o l o g i . f i s i p-$ unmul.ac.id\%2Fsite $\% 2$ Fwpcontent $\% 2$ Fuploads $\% 2 \mathrm{~F} 2014 \% 2 \mathrm{~F} 05$ $\% 2$ F3.\%2520ISI\%2520JURNAL \%25 20\%2805-24-14-03-5323\%29.pdf\&usg=AFQjCNEeWUpkg GxkVPuvogQYhYPThJOdug\&cad=rj a

Sartana., Helmi, A.F. (2014). "Konsep diri remaja Jawa saat bersama teman", Jurnal Psikologi, 2, 41, diunduh pada tanggal 21 Desember 2016 dari https://jurnal.ugm.ac.id/jpsi/article/do wnload/6949/5410

Sembiring. (2014). Pengertian Self Confidence. Universitas Sumatera Utara.

Siregar, S. (2013). Metode Penelitian Kuantitatif Dilengkapi Perbandingan Perhitungan Manual \& SPSS. Jakarta: Prenadamedia Group.

Sugiyono. (2012). Metode Penelitian Kuantitatif dan Kualitatif. Bandung : Alfabeta.

Sugiyono. (2014). Metode Penelitian Kuantitatif, Kualitatif dan R\&D. Bandung : Alfabeta.

Wahyuni, S. (2014). "Hubungan Antara Kepercayaan Diri dengan Kecemasan Berbicara di Depan Umum pada Mahasiswa Psikologi”, 2, 1, e-journal Psikologi, diunduh pada tanggal 21 Desember 2016 dari 
http://ejournal.psikologi.fisip-

unmul.ac.id/site/wp-

content/uploads/2014/04/JURNAL\%2

OSRI\%20WAHYUNI\%20(04-16-14-

04-07-51).pdf

Yildirim, C. (2014). Exploring the

dimensions of nomophobia:

Developing and validating a

questionnaire using mixed methods

research, Graduate Thesis and

Disertations, diunduh pada tanggal 21

Desember 2016 dari

http://lib.dr.iastate.edu/cgi/viewconten t.cgi?article $=5012 \&$ context $=$ etdArif,

I.S. (2006). Skizofrenia: Memahami dinamika keluarga pasien. Bandung: Refika Aditama. 